\title{
国際原子カエネルギー・パートナーシップ構想，核然料 供給保証構想への日本の対応
}

\begin{abstract}
近年, 各国で原子力発電の重要性が再認識され, 原子力発電の拡大・導入が計画・検討され ている。一方，イランの核開発問題や北朝鮮の核実験などに見られるように，国際社会は核不 拡散強化のための対応に迫られている。原子力平和利用の拡大を容認しつつ核拡散防止を眓る ため, 米国提案の「国際原子力エネルギー・パートナーシップ」構想, 核燃料供給保証構想, 口 シア提案の核燃料サイクル・サービス提供のための「国際センター」構想などが相次いで提案・ 議論されている。

非核兵器国として原子力平和利用の模範を示してきたわが国として, これらの原子力平和利 用と核不拡散の両立に関する国際的枠組み作りの議論等に積極的・主体的に参画し, 貢献して いくことが重要である。
\end{abstract}

\section{I . 原子力平和利用と核不拡散に関する} 国際的枠組みについての多様な提案

2006年 7 月の $G 8$ 首脳会合サンクトペテルブルグ会議 の合意文書に「原子力エネルギーは気候変動問題等への 対応と同様にエネルギー安全保障に資する」との言葉が 盛り达まれた。これに象徵されるように，近年，世界的 に原子力発電の重要性の再認識が搪がり, 各国で原子力 発電の拡大・導入が計画・検討されている。その一方 で, イランの核開発や北朝鮮の核実験など, 核兵器の拡 散に対する国際社会の懸念は深刻の度を増している。こ うした状況のもと, この 2,3 年の間に, 原子力平和利 用の拡大と核不拡散の両立のための新たな国際的枠組み について, 様々な提案・議論が行われている。

2005年のノーベル平和賞を受賞した国際原子力機関 (International Atomic Energy Agency:IAEA)のエル バラダイ事務局長は，2004年 6 月，国際専門家グループ に「核燃料サイクルのマルチラテラルアプローチ (Multilateral Approaches to the Nuclear Fuel Cycle:

Greating a International Framework to Uphold both NonProliferation and the Global Expansion of Nuclear PowerJapan's Contribution to the Global Nuclear Energy Partnership and Assurance of Nuclear Fuel Supply: Shinichi MIZUMOTO.

(2006年 11 月22日 受理)
MNA)」に関する検討を要請した。国際専門家グループ は，2005年 2 月に複数の選択肢を提案した報告書.1 を取 りまとめている。なお, エルバラダイ事務局長は, 国際 専門家グループの検討とは別に, 個人的見解として, 濃 縮・再処理施設新規建設の 5 年間凍結構想を表明した が,これは公式には提案されていない。

ブッシュ米大統領は, 2004 年 2 月, 大量破壊兵器の不 拡散に関する演説で, (1)濃縮・再処理技術および資機材 の移転制限, (2)濃縮・再処理を放棄した国への核燃料供 給保証の創設を提案した。これらの提案に関しては, そ の後の $\mathrm{G} 8$ 首脳会合において合意がなされ, (1)について は, 原子力供給国グループ(Nuclear Suppliers Group： NSG)で鋔意検討が進められている。(2)については, 2006 年 6 月の IAEA 理事会に濃縮ウラン輸出 6 力国(仏, 独, 蘭, 露, 英, 米)から核燃料供給保証のコンセプト が提案され，9月の IAEA 総会の特別イベントで議論 が行われた。(詳細および日本の対応を後述)

また，米国は，2006年 2 月に「国際原子力エネルギー・ パートナーシップ(Global Nuclear Energy Partnership : GNEP) 」構想を発表した。これは, 先進的な再处理技術 と高速炉の開発により放射性廃裹物の低隇を目指すとと もに，核燃料サイクルに関する新たな国際的枠組みの創 設を提案するものである。（詳細および日本の対応を後 述)

一方，ロシアのプーチン大統領は，2006年 1 月，ウラ 
ン濃縮を含む核然料サイクル・サービスを提供する複数 の「国際センター」を設置し，その一つをロシアに設置す ることを提案した。ロシアはこの「国際センター」は IAEA の保障措置を受け，から国際的に運営されるもの で， ウラン濃縮掞よび再処理に関する機微技術および施 設を自前で保有することを断念した国に対して，無差別 から合理的な商業的条件で濃縮抒よび再処理のサービス を提供するものであると説明している。また，最初のス テップとして，ロシアにウラン濃縮の「国際センター」を 設置するとしている。

\section{II. わが国は原子力平和利用と核不拡散 の両立の模範国}

わが国は，国際的な信頼の下に，非核兵器国の中で唯 一商業規模の核燃料サイクルを保有している。ここに至 るまでには，永年にわたるわが国の原子力平和利用・核 不拡散に関する努力があった。

例えば，わが国は核兵器不拡散条約 (Treaty on the Non-Proliferation of Nuclear Weapons:NPT)の非核兵 器国として，核兵器の製造や取得等を行わないとの責務 を莩守するとともに，NPT 普遍化のための努力を積極 的に続けている。

わが国のみに特徵的な努力として, 米, 英, 仏, IAEA 等と協力して, 大型商業再処理施設に対する保障措置手 法の検討・開発・実証を行った。こうした努力の結果, 2004年 1 月には，IAEA による世界初の大型商業再処理 施設に対する保障措置が六ヶ所再処理工場に適用され た。さらに2004年 9 月には，これまでのわが国の徽底的 な原子力の平和利用の実績が認められ，大規模な原子力 活動を行う国として初めて，わが国の原子力発電所等へ の IAEA 統合保障措置(IAEA が，核物質の転用や未中 告の活動等の兆侯がないと確認した上で，当該国に対す る查察の合理化・效率化を行う制度)の適用が開始され ている。

また，東海再処理施設の建設にあたっては，純粋なプ ルトニウム酸化物単体が存在することがないよう，世界 で初めて硝酸ウラン溶液と硝酸プルトニウム溶液を混合 させて MOX 粉末を生成するという再处理技術の開発を 行った。

このような努力の結果により，わが国の原子力平和利 用の透明性が確保され，国際的な信頼が得られている。

原子力基本法の平和利用の基本方針（「原子力の研究, 開発掞よび利用は，平和の目的に限る」) と非核三原則 （「核兵器を持たず，作らず，持ち込ませず」）も，わが国 の原子力平和利用の確保の上で重要である。これらにつ いて，「国内法や国内政策は国家の意思により変更が可 能であり，国際的な信頼の基礎とはなり得ないのではな いか」との指摘がある。この指摘は一面の真実であるか
もしれない。しかしながら，原子力基本法と非核三原則 が自制力として働いていることが，これまでわが国が厳 に原子力平和利用に微してきた大きな要因であり，ま た，今後においても重要な役割を果たすであろうことは 論をまたないであろう。筆者は，核不拡散のための国際 的枠組みを構築し，核拡散抵抗性を高めるための技術開 発を行っても核拡散リスクを完全にゼロにすることは不 可能であり，これらと併せて，原子力基本法や非核三原 則のような自律的に核兵器開発を抑止するためのソフト 面での刘応も，日本のような国においては有効な手段だ と考えている。

以上の上うな努力・取組みを通じて, 原子力平和利用 と核不拡散の両立の模範国となっているわが国は, GNEP 構想などの新たな国際的朹組み作りの動きに対し て，単に日本の特殊性を主張するだけでなく，これまで の経験や技術を最大限に活かし，積極的に協力・貢献を 行うことが重要である。

\section{GNEP 構想へのわが国の対応}

\section{1. 米国の GNEP 構想の発表とわが国の対応}

米国が2006年 2 月に発表した GNEP 構想には, 国内 政策と国際政策の 2 つの側面がある。

\section{（1）米国の国内政策の方針転換}

これまで米国は，民生用原子力発電所からの使用済燃 料を直接処分する方針をとり，再処理や高速炉の開発・ 導入には消極的であった。しかしながら，2010年までの 操業開始を予定していたネバダ州ユッカマウンテン処分 場の建設計画が同州知事の提訴等により遅れが生じてお り，また，ユッカマウンテン処分場が建設されたとして も，2015年頃から使用济燃料の処分場が不足するという 問題点が指摘されていた。

こうした背景の下, 米国は GNEP 構想を発表し, 放 射性廃亲物を減らすため, 核拡散抵抗性に優れた(プル トニウムを単体で分離しない)先進的再处理技術の開発 を促進するとともに, 取り出されたプルトニウム等を燃 やすための高速炉の開発を進めるとの方針に転じた。

（2）新たな国際枠組みの提案

また, GNEP 構想では, 開発途上国等への原子力発電 の拡大を許容しつつ, 機微技術である濃縮・再处理技術 の㕬散を抑止するための新たな国際朹組みの創設を提案 している。具体的には,

(1) 核燃料サイクル国(米, 日，仏，英，露，中，等 が想定されている) は, 先進的再処理抢よび高速炉 を開発・利用する。(第 1 表参照)

(2) 開発途上国を含め, 核燃料サイクル国以外の国(発 電国) は, 濃縮・再处理技術の獲得を放棄すること により，核燃料サイクル国から発電用核燃料を適正 価格で供給され，原子力発電を行う。 
第 1 表 各国の原子力発電・再処理の現状

\begin{tabular}{|c|c|c|c|c|}
\hline & 国 名 & 原発数 & 再処理施設 & 備 \\
\hline \multirow{6}{*}{ 核燃料サイクル国 } & 日 本 & 55 & 0 & 東海、六ヶ所 \\
\hline & 米 国 & 103 & $x$ & $\begin{array}{l}\text { これまだ使用済燃料を直接処分する方針であったため、商業 } \\
\text { 用再処理は行っていはい。 } \\
\text { 再処理の研究は実施。 } \\
\end{array}$ \\
\hline & フランス & 59 & $\mathrm{O}$ & ラ・アーグ \\
\hline & ロシア & 31 & $\mathrm{O}$ & チヤリ+ビンスクー40(マヤーク) \\
\hline & 英 国 & 23 & $\mathrm{O}$ & 也ラフィールド \\
\hline & 中 国 & 9 & $\begin{array}{c}\triangle \\
\text { (パイロトフララント) }\end{array}$ & フランスの協カで大規模再処理施設の建設計画有。 \\
\hline \multirow{7}{*}{ その他の原子力発電国 } & インド & 15 & 0 & タラプール、カルパカム \\
\hline & 韓 国 & 20 & $x$ & \\
\hline & ドイツ & 17 & $x$ & \\
\hline & カナダ & 18 & $x$ & \\
\hline & スウェーデン & 10 & $x$ & \\
\hline & スペイン & 9 & $x$ & \\
\hline & その他 & 71 & & \\
\hline \multicolumn{2}{|l|}{ 総計 } & 440 & & \\
\hline \multirow{2}{*}{ 原子力発電導入検討国 } & ベトナム & & $x$ & 2017〜2020年に運転開始を目指す。 \\
\hline & インドネシア & & $x$ & 2020年までに運転開始を目指す。 \\
\hline
\end{tabular}

（3）発電国は使用済燃料を核燃料サイクル国に返還す る。

(4) 併せて, 核然料サイクル国は開発途上国のニーズ に応じた原子炉の研究開発, 導入協力についても検 討する。

（3）GNEP 構想発表に対するわが国の対応

GNEP 構想が発表されてすぐに，以下のとおり，わが 国の関係省庁が連名で GNEP 構想への協力を検討する 旨の見解を発表した。

(参考)米国「国際原子力エネルギー・パートナー シップ」(GNEP, Global Nuclear Energy Partnership) 構想に対する見解

2006年 2 月 7 日 内閣府

外枒省

文部科学省

経済産業省

米国が，原子力発電の世界的な発展拡大を許容し つつ核不拡散を確保するための構想を提案したこと を評価する。

また，本構想が，エネルギー効率を高め，放射性 廃菓物を低減するため，使用済燃料のリサイクルを 進める方向を明示したことは，米国の新たなイニシ アティブとして注目される。
我が国としては，今後，どのような貢献ができる かという観点から，本構想に関する検討を行ってい く考えである。

一方，米国のブッシュ大統領およびエネルギー省副長 官から，GNEP 構想に対する日本の協力への期待が表明 されている。

なお, GNEP 構想とわが国の再処理事業との関連で は，米国政府から日本政府に刘して，「GNEPによって， 六ヶ所再処理工場や東海再処理施設に対する従来の日米 原子力協定に基づく米国の同意に何ら影響を与えるもの ではない」，「発電国からの使用済燃料の返還を受け入れ る国は商業ベースで決まるものであり，特定の国での受 入れを強制されることはない(すなわち, GNEPにより 六ヶ所再処理工場が海外の使用済燃料の受入れを強制さ れることはない)」との説明がなされている。

\section{2 トラックアプローチへの変更}

当初の GNEP 構想では, 国立研究所を中心として, 革新的な再処理技術等を前提にした長期的な研究開発を 実施する計画が提示されていた。しかしながら，産業界 出身のスパージョン次官補が米国エネルギー省 (DOE) の GNEP 構想の実施責任者に就任し, GNEP構想の進 め方について軌道修正がなされた。現実に切迫した問題 となっている膨大な使用済燃料を処理し，すでに産業界 が有している技術・知見を活用するとの観点から，2006 年 8 月, DOE は GNEP 構想を 2 段階 ( 2 トラックアプ 
ローチ)で進めると発表した。

トラック 1 (第 1 段階)では, 産業界の技術を活用し て，2020年頃までに「先進的燃燒灯 (Advanced Burner Reactor: ABR)」(電気出力 $20 \sim 80$ 万 $\mathrm{kW}$ ) と「統合核燃料 取扱センター (Consolidated Fuel Treatment Center: CFTC)」(再処理および燃料製造施設。処理能力 100 $1,000 \mathrm{t} /$ 年)を建設する。このために, 国内外の企業等 から関心意四表明(Expression of Interest:EOI)を募集 する。

トラック 2 (第 2 段階)では, 当初の計画どおり, マイ ナーアクチニド $(\mathrm{MA})$ とプルトニウムをともに分離・回 収する先進サイクル技術の研究を実施し, 「先進的核燃 料サイクル施設 (Advanced Fuel Cycle Facility: $\mathrm{AFCF}) 」 の$ 建設に向けた研究を実施する。

日本は2006年 9 月，これまで日本が開発してきた技術 システムが国際標準となることを目指す推点から, 日本 原子力研究開発機構. (JAEA), 国内メーカー各社, 日本 原然(CFTCのみ)が連名で, EOIへの技術提案を行っ た。

わが国は GNEP 構想に対して, 核不拡散と原子力の 平和利用を実現している模範国として, 高速増殖灯や再 処理施設等に関する経験や技術を最大限に活かし, 積極 的に協力・貢献していく方針である。トラック 1 に関し ては，米国における今後の進め方を注視し，関係省庁， JAEA および产業界が連携・協力して対処する。トラッ ク 2 に関しても, 引続き研究協力の提案を積極的に行 い, 協力を具体化していく。

\section{N. 核燃料供給保証構想へのわが国の対応}

\section{1. 核然料供給保証 6 力国提案と各国の反応}

濃縮・再処理を放裹した国への核燃料供給保証の創設 に関しては，2006年 6 月の IAEA 理事会で，濃縮ウラ ン輸出 6 カ国からコンセプト案が提案された。この 6 力 国提案は，濃縮役務および濃縮ウランの供給保証に焦点 をあて, (1)市場原理による供給, (2IAEAのエンドース による供給保証，(3)部の国による備蓄の 3 層による然 料供給保証体制の構築を提案している。また，このメカ ニズムはあくまでも通常の商業プロセスで解決できない 場合の最後の手段であるとしている。

IAEA 6 月理事会では， 6 力国提案に刘して途上国を 中心に以下のような眯念・疑問が表明された。

ONPT 第 4 条に規定される各国の自主的な核然料サ イクル開発の権利は保障されるべき。

○受領国の参加条件にある「核燃料サイクル技術開発 の放菄」は受け入れられない。

○本件構想は平和目的の研究開発活動の権利を奪い, 市場独占化を目指すものであり受け入れ困難。

\section{2. 日本の提案}

わが国は 6 力国提案の目的には賛成であるものの， IAEA 6 月理事会で各国から奬念・疑問が表明されたこ とを踏まえ，2006年 9 月の IAEA 総会に際して 6 力国 提案を補完するための日本提案を行うこととした。 IAEA 総会の日本政府代表演説において，松田科学技術 政策担当大臣(当時)からご提案をいただき，IAEA 総会 に併せて開催された「21世紀の原子力利用の新たな枠組 み：供給保証と核不拡散」と題する特別イベントにおい て, 近藤原子力委員会委員長から日本提案の内容を説明 していただいた。

日本提案を行うことは,また,(1)わが国が国際的なルー ルメーキングに貢献することを各国に認識させ，ルール メーカーの一員としてのプレゼンスを確保すること，(2) 「供給国」の地位を現在の濃縮ウラン輸出 6 力国に固定さ れることがないよう, 将来の輸出について柔軟性を確保 するルールを提唱していくこと，(3)今後の核然料供給保 証に関する議論 (専門家会合など)に積極的に参加する姿 勢を明確に示すことにも資すると考えられた。

日本提案は，IAEA を受け吕として，各国が自発的に フロントエンドの能力 (現保有量, 供給キャパシティな ど)を登録するものである(「IAEA 核燃料供給登録シス テム (IAEA Standby Arrangements System for the Assurance of Nuclear Fuel Supply) 」2)。このメカニズム は, ウラン濃縮に限らずフロントエンド全体(ウラン原 料, 転換, 濃縮, 燃料加工, ウラン在庫・備蓄等)をカ バーしている。また， 6 力国提案では「供給国」と「受領 国」の「二分法」となっているが，日本のように濃縮ウラ ンを生産しているが現時点では輸出していない国など, 「二分法」では分類できない国がある。このため，こうし た多様な実態を反映できるよう，登録にあたってレベル 分けを行っている(レベル 1 ：商業生産をすでに開始し ているが, 商業規模での輸出はしていない, レベル $2 ：$ すでに商業規模での輸出を行っている，レベル $3:$ 短期 間で輸出可能な備蓄を有している)。この日本提案によ り，多くの国が核燃料供給保証の枠組みに自主的に参 加・貢献できると考えられる。

\section{IAEA 総会特別イベントでの議論と今後}

2006年 9 月の IAEA 総会特別イベントでは， 6 カ国 提案, 日本提案のほか, 英国, 独外相, 世界原子力協会 (World Nuclear Association:WNA), 核脅威イニシア ティヴ(Nuclear Threat Initiative : NTI)による提案も紹 介され，3 日間に及ぶ議論が行われた。

この特別イベントにおいて, 日本提案は一定の評価を 受けており，IAEA および各国は，わが国がルールメー カーとして貢献する国であることを認識したと考えられ る。

特別イベントでは，具体的なメカニズムについての結 
論・方向性は決定されなかったものの，特別イベント議 長のIAEA 総会への報告では, (1)核燃料供給保証に関 する各提案は相互に雨立可能であり補完的と見られるこ と, (2)今後, IAEA 事務局は, 政策的·技術的・法的問 題の検討により核然料供給保証に関する提案を成熟さ せ, 加盟国, 産業界, 専門家の協力の下, 理事会に提案 を提出すべきこと等が言及された。

わが国としては, 今後も核燃料供給保証に関する議論 に積極的に参加し，できるだけ多くの国が参加でき，か つ, わが国の原子力の発展にとっても有益なメカニズム の構築のために努力していく考えである。

\section{V．結びに}

わが国は，安全で信頼性の高い原子力技術をもとに， 原子力の平和利用に徹し, 世界の原子力において重要な 位置を占めるに至っている。世界的な原子力平和利用の 拡大と核不拡散の両立のため, 政府, 研究機関, 産業界 が連携・協力して，GNEP 構想や核燃料供給保証構想な どの国際的な動きに，一層積極的かつ的確に対応してい
く必要がある。

\section{一参 考 文 献一}

1) International Atomic Energy Agency, Multilateral Approaches to the Nuclear Fuel Cycle: Expert Group Report submitted to Director General of the International Atomic Energy Agency, INFCIRC/640, 22 February 2005.

2) International Atomic Energy Agency, Japan's Proposal: IAEA Standby Arrangements System for the Assurance of Nuclear Fuel Supply, INFCIRC/683 Attachment, 15 September 2006.

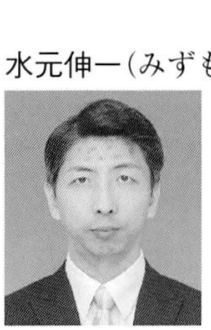

\section{著者紹介}

経済産業省 資源エネルギー庁 原子力政策 課

(専門分野/関心分野) 原子力・核燃料开イ クル政策

\section{お知らせ}

\section{Journal of Nuclear Science and Technology (英文論文誌) 電子アーカイブ作成に伴う過去論文の著作権取扱いについて}

このたび，当学会発行の Journal of Nuclear Science and Technology (以下，英文論文誌)が，(独)科学技術振興 機構(JST)電子アーカイブ事業に採択されました。これにより，1964年の創刊号に遡り，電子アーカイブ化され， インターネットで無料公開されることとなります。

この電子アーカイブ事業は, 国内学協会の学術雑誌の国際発信力の強化と重要な知的財産の保存等を目的とし, さらに特に重要な学術雑誌について過去の紙媒体の論文に遡り学術の振興・研究成果を共有できるよう過去の論文 を電子化し論文を広く世の中に広め，後世の研究に役立てるという意義を持っています。

電子アーカイブ化を行うにあたり，当学会は著者から著作榷の権利譲渡・許諾を受ける必要があります。英文論

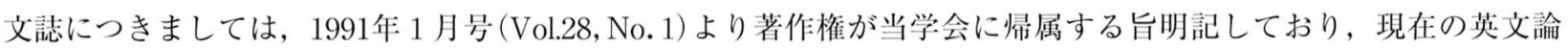
文誌においては更に著作権譲渡の書面を著者と学会との間で取り交わし，著作権の学会への帰属を明確にしており ます。しかしながら，1990年以前の英文論文誌においては，国内学会誌でそのような慣行がまだ明確化されていな かったため，論文の著作権譲渡について明確な記述がない状況です。そのため，1990年以前に英文論文誌に掲載さ れた著者の皆様には, 本電子アーカイブ事業の目的と意義, 著作権対応経緯をご理解いただき, 著作榷の譲渡・許 諾をお願いする次第です。

掲載論文の著作榷の譲渡・許諾にご同意いただきたくことにつきまして，異議がございましたら，2007年 3 月 30 日(金)までに当学会までご連絡くださいますようお願い申し上げます。期限までに異議が無い場合は, 順次電子アー カイブ化の準備に入らせていただきます。

本件連絡先 社団法人 日本原子力学会 事務局

TEL 03-3508-1261, FAX 03-3581-6128

E-mail : hensyu@aesj.or.jp 